\title{
Sources and migration path of chemical compositions in a karst groundwater system during rainfall events
}

\author{
YANG PingHeng $^{1,2^{*}}$, YUAN DaoXian ${ }^{1,2}$, YE XuChun $^{1}$, XIE ShiYou ${ }^{1}$, CHEN XueBin $^{1} \&$ \\ LIU ZiQi ${ }^{1}$ \\ ${ }^{1}$ School of Geographical Sciences, Key Laboratory of Eco-environments in Three Gorges Reservoir, Ministry of Education, Southwest University, \\ Chongqing 400715, China; \\ ${ }^{2}$ The Karst Dynamics Laboratory, Ministry of Land and Resources, Institute of Karst Geology, Chinese Academy of Geological Sciences, \\ Guilin 541004, China
}

Received July 18, 2012; accepted January 5, 2013; published online March 26, 2013

\begin{abstract}
Physical and chemical dynamics at Jiangjia Spring (JJS), the outlet of the Qingmuguan karst groundwater system in Chongqing, were monitored in situ during rainfall events to acquire a series of high-resolution data. Principal component analysis (PCA) was employed to identify the sources of chemical compositions in the karst groundwater. The coefficients of variations (CVs) of the physical and chemical data of JJS were utilized to interpret the migration path of the chemical compositions. The results showed that water-rock interactions, agricultural activities, and soil erosion were the main sources of the groundwater chemical compositions. Ions of potassium, sodium, nitrate, chloride and phosphate from agricultural activities together with ions of calcium, magnesium, strontium and bicarbonate derived from carbonate dissolution appear to be stored and regulated by the karst unsaturated zone in features such as fissures, pores and solution cracks. The concentrations of the ions remained relatively stable and they showed low CVs owing to their migration by diffuse flow to recharge the underground river. In contrast, concentrations of ions such as total iron, total manganese and aluminum from soil erosion were unstable and showed high CVs owing to their migration by overland flow to recharge the underground river directly via sinkholes. During heavy rainfall events, the nutrients from agricultural activities and sediment from soil erosion could quickly impair the aquatic ecosystem and pose serious threats to water quality. Therefore, it is necessary to reinforce management of the ecological system for better control of the influx of mass nutrients into the karst aquifer system.
\end{abstract}

karst groundwater, chemical composition, source, migration path, diffuse flow, conduit flow

Citation: Yang P H, Yuan D X, Ye X C, et al. Sources and migration path of chemical compositions in a karst groundwater system during rainfall events. Chin Sci Bull, 2013, 58: 2488-2496, doi: 10.1007/s11434-013-5762-x

The karst areas of SW China are typically vulnerable ecological regions that represent the largest consecutive distribution and most intense karstification in the world. Despite the areas being favored with good water and heat conditions in the subtropical zone, they have extremely heterogeneous water distributions due to long-term karstification. This has led to the formation of a karst soil and water resource environment with several issues including structural water shortage, infertile soil, and ecological vulnerability [1]. In recent years, the karst water resources in the area have be-

*Corresponding author (email: balance@swu.edu.cn) gun to dry up and the pollution sources have become diversified under the obvious and increasing influences of anthropogenic activities and extreme climates [2]. This has become a hindrance to the sustainable economic and social development of the area.

Hydrochemical compositions are the basis for investigations of groundwater and surface runoff sources and are crucial to groundwater resource evaluation. Accordingly, they play a significant role in the utilization and management of groundwater resources in a watershed as well as the protection and construction within the related ecological environments. Geochemical analysis is a commonly used 
method for investigations of groundwater origin, recharge source, hydraulic connections, and water-rock interactions [3-12].

Karst geochemistry is a branch of geochemistry that studies the principles and application of chemical action in karst dynamic systems [10]. Previous studies using conceptual models of karst dynamics [13] and the historic perspective of research on karst groundwater geochemistry [14-17] have primarily focused on the physical and chemical compositions (e.g. $\mathrm{Ca}^{2+}$, conductivity, hardness, etc.) associated with the water-rock interactions of karst groundwater. Because of limited research methods, the research parameters are less diversified and cannot comprehensively reflect the influences from substances of the surface environment on karst groundwater. Most studies to investigate the influences of anthropogenic activities on karst groundwater geochemistry have compared different chemical parameters of the karst water in different spaces within the same period, or at the same research site in different periods (e.g. a year, a season, etc.). However, such data in the studies are usually contingent, the prerequisite of comparisons are insufficient, and the descriptions are superficial and probably cannot comprehensively reflect the sensitivity of the karst system. In addition, comparison of hourly data (high-resolution monitoring) and monthly data results in a significant discrepancy invalidating the latter as an indicator of rapid changes in karst groundwater systems [18,19]. Therefore, investigations of karst groundwater systems with high sensitivity and vulnerability to influencing factors from the surface environment must be based on not only the chemical compositions in the karst groundwater system, but also the collection of high-resolution data describing those hydrochemical parameters.

However, high-resolution monitoring could generate a tremendous volume of data and, in most cases, redundant information; therefore, a proper method for analysis is necessary. Principal component analysis (PCA) can combine a large number of correlated variables into a few uncorrelated parameters, transfer the former numerous variables into useful information and facilitate further analysis. So PCA is widely applied in the research of geosciences [20-25].

The coefficient of variation (CV) describes the variation amplitude of a variable, with a larger variation in amplitude being associated with a larger $\mathrm{CV}$, and vice versa. CVs of the chemical parameters of a karst spring reveal important information about groundwater recharge sources and migration paths $[14,17,26]$.

During rainfall events, the geochemical behavior of karst groundwater responds quickly to the rainfall, and the groundwater system sufficiently exchanges substances and energy with the external environment [27]. In this study, a process for high-resolution data collected at Jiangjia Spring (JJS), the outlet of the Qingmuguan groundwater system in Chongqing, during rainfall events in late May 2009 is introduced. High-resolution hydrochemical data are presented and PCA is employed to identify the sources of chemical compositions. Based on the results of PCA and the characteristics of the CVs of physical and chemical parameters, the migration path of chemical compositions in the karst aquifer is proposed. These results of this investigation also help explain the interaction between karst groundwater and the surface environment, effectively forecast karst groundwater pollutants, and provide a scientific basis for rational exploitation of karst groundwater resources.

\section{Descriptions of the test site}

The Qingmuguan groundwater system is located in western Chongqing, the largest municipality in China (Figure 1). The system was selected by Southwest University as a field monitoring site for studying karst dynamics in 2007. The system is a typical karst aquifer that is well-suited as a hydrogeological field base for teaching practices under the United States Agency for International Development (USAID) China Environmental Health Project.

At the test site, the stratum consists of carbonate of the lower Triassic Jialingjiang formation $\left(\mathrm{T}_{1} j\right)$ with a thickness greater than $600 \mathrm{~m}$. Exposed at the anticlinal axis, it is the oldest stratum at the site and is the main body of the mountain. Lithologically, the formation is mainly composed of grey thick massive limestone, dolomite, dolomite limestone and brecciaous limestone. The NE and NW shear fractures and the longitudinal and latitudinal tension fractures at the anticlinal core are well developed. Under the long-term corrosion of karst water, a valley was formed. Both limbs of the anticline are in the carbonate stratum of the middle Triassic Leikoupo formation $\left(\mathrm{T}_{2} l\right)$ and the feldspathic quartz sandstone, pelitic siltstone, and mudstone bedding coal layer of the upper Triassic Xujiahe formation $\left(\mathrm{T}_{3} x j\right)$, with a thickness greater than $700 \mathrm{~m}$. Under the two extrusion stresses at the turn of the axis limb, the extruded faulted and fractured zone is formed at the east and west sides of the anticlinal axis. Therefore, two ridges emerge at both sides of the anticlinal mountain, where they are manifested by the typical karst valley landform, one mountain, two ridges, and one valley. The altitude of the highest site in the north part is $705 \mathrm{~m}$ a.s.1. at Zhutoushi, whereas the lowest is $310 \mathrm{~m}$ a.s.l. at the south end. The altitude gradually decreases from north to south.

An underground river approximately $7.4 \mathrm{~km}$ in straightline distance flows from NNE to SSW through the carbonate stratum (Figure 1). The main headstream of the underground river is the Yankou sinkhole, into which the surface water enters. The underground river is also recharged by water from other sinkholes and karst fissures, pores and solution cracks. The watershed boundary is consistent with the surface watershed boundary and has an area of about $13.4 \mathrm{~km}^{2}$. The underground river discharges at JJS (about $320 \mathrm{~m}$ a.s.l.) at the south end of the drainage basin. JJS is an 
intermittent spring with discharge that fluctuates greatly $\left(0-3.5 \mathrm{~m}^{3} \mathrm{~s}^{-1}\right)$ with storm events that generally dries out from December to March.

The test site is subject to the subtropical humid monsoon climate and has a mean annual precipitation of $1250 \mathrm{~mm}$ and a mean annual temperature of $16.5^{\circ} \mathrm{C}$. Forest is the main land-use type, which accounts for $64 \%$ of the watershed and is mainly distributed on the sides of the valley. Paddy fields account for $6 \%$ of the land use and are mainly distributed at the depression of Ganjiacao in the upper area of the drainage basin. Dry fields account for $28 \%$ of the land use and are mainly distributed inside the depression or on the slopes of the depression in the upper and middle stream. Paddy soil is distributed at an average thickness of 1 $\mathrm{m}$ in the karst valley of the study area, mostly with detrital limestone. Yellow mineral soil is found on the karst valley slopes and footslopes. The soil varies greatly in thickness, ranging from 0.2 to $2 \mathrm{~m}$, but is thin in most of the area. The soil at both limbs of the anticline is yellow sand soil and usually $1-2 \mathrm{~m}$ thick.

\section{Materials and methods}

\subsection{Field monitoring}

A rectangular open channel was built at the outlet of the JJS to conduct accurate discharge observations. The channel is about $10 \mathrm{~m}$ long, $2.1 \mathrm{~m}$ wide and $1.5 \mathrm{~m}$ tall. A WGZ-1 photovoltaic gauge (Chongqing Huazheng Hydrometric Instrument Co., Ltd.) with an accuracy of $1 \mathrm{~mm}$ was mounted $5 \mathrm{~m}$ away from the JJS to monitor the water level in real time. The water level was converted to discharge according to an empirical formula of a rating curve [18]. A CTDP300 automatic multi-parameter recorder (Greenspan Company) was used to record the specific conductance ( $\mathrm{Spc}), \mathrm{pH}$ and temperature of the groundwater with an accuracy of 0.1 $\mu \mathrm{S} \mathrm{cm}{ }^{-1}, 0.01$ and $0.01{ }^{\circ} \mathrm{C}$, respectively, each at $15 \mathrm{~min}$ intervals. An FL30 flow-through field fluorometer (Albillia Company) was used to measure the turbidity of the groundwater with an accuracy of 0.01 NTU at intervals of 4 min. A HOBO automatic weather station (ONSET Company) with an accuracy of $1.0 \%$ was set at the Silengbei to observe rainfall.

\subsection{Field sampling}

A total of 85 water samples were automatically collected every $2 \mathrm{~h}$ by a Sigma900 sampler (Hatch Company). After six samples were collected, the samples were removed from the sampler and preprocessed for anionic and cationic analysis. The water samples for cation and anion analyses were collected in sterile $60 \mathrm{~mL}$ and $1 \mathrm{~L}$ polyethylene narrowmouth, screw-cap bottles. The water samples for cation analyses were immediately acidified to $\mathrm{a} \mathrm{pH}<2$ by adding several drops of ultrapure nitric acid. All water samples were refrigerated at $4^{\circ} \mathrm{C}$ until analysis, which was conducted within $10 \mathrm{~d}$ of sampling.

\subsection{Laboratory analysis}

The concentrations of anions were measured using the method for examination of drinking water (GB/T 85382008) [28]. Concentrations of cations were determined using an Inductively Coupled Plasma Optical Emission Spectrometer (ICP-OES, PerkinElmer Ltd.) with a stability of $\mathrm{RSD}<1 \%$ in $1 \mathrm{~h}$. All these measurements were carried out at the Laboratory of Geochemistry and Isotope, and the Laboratory of Karst Water Resources, Southwest University.

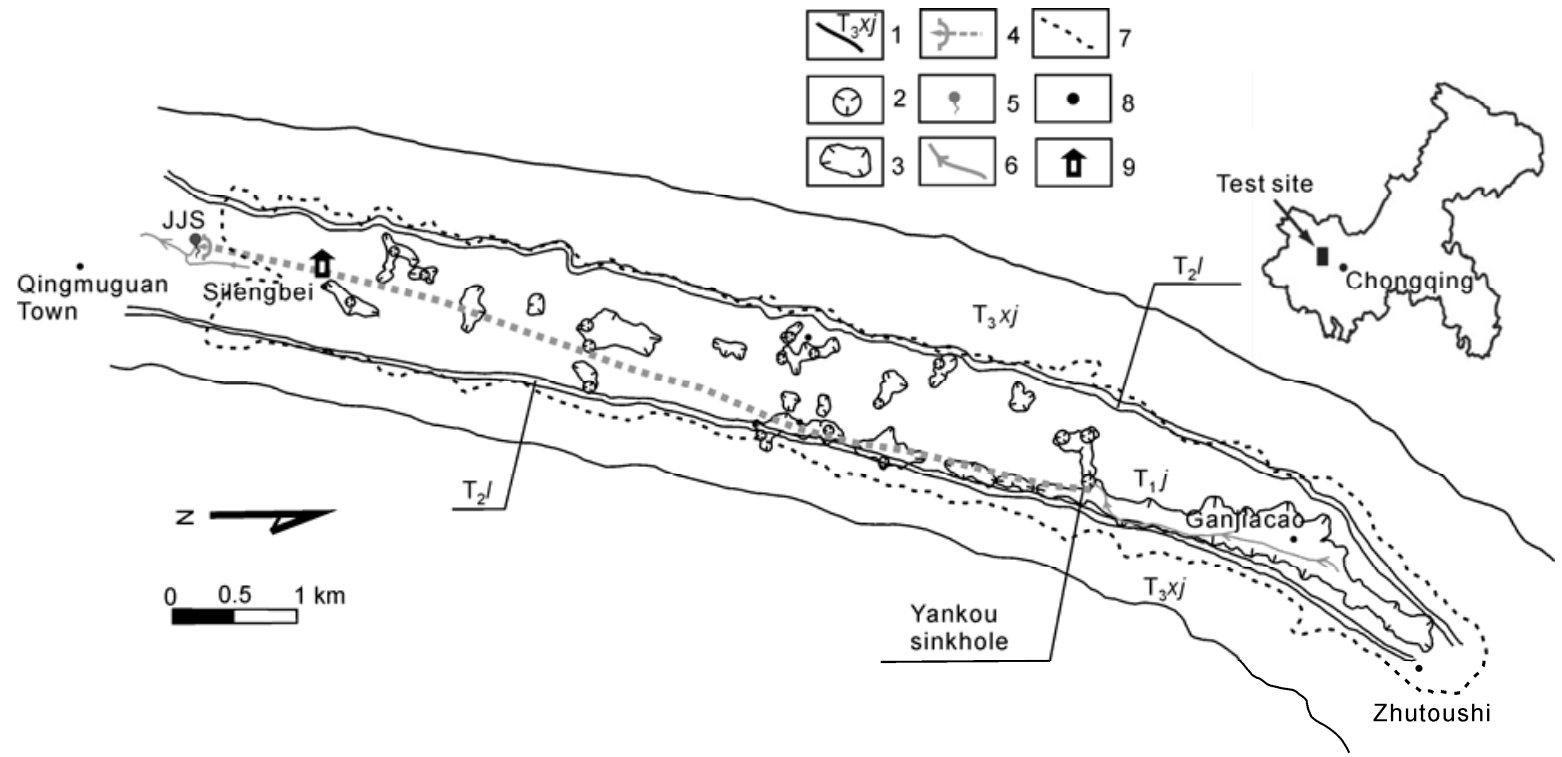

Figure 1 Hydrogeological map of the test site. 1, Stratum boundary and its stratigraphic chronology; 2, sinkhole; 3, depression; 4, underground river and its outlet; 5, JJS; 6, surface flow; 7, watershed boundary; 8, site; 9, weather station. 
Examination of the anion-cation balance in water was calculated with a relative error less than $5 \%$, indicating that the data are reliable [3].

\subsection{PCA and CV}

PCA is supported by the idea of reducing dimensions. A large number of correlated variables are recombined into a few uncorrelated parameters to replace the former numerous variables, facilitating further analysis. The specific principles of PCA are outlined elsewhere [29]. The calculation of PCA was conducted using software of SPSS 19.

$\mathrm{CV}$ is also known as the relative standard deviation (RSD). A smaller CV value is associated with less deviation of a variable from the average value, and vice versa. The $\mathrm{CV}$ is the ratio of the standard deviation to arithmetic mean value:

$$
\mathrm{CV}=\sigma / \bar{x}
$$

where $\mathrm{CV}$ is the coefficient of variation; $\sigma$ is the standard deviation; $\bar{x}$ is the arithmetic mean.

\section{Results}

\subsection{Response of hydrochemistry to rainfall events}

There were three intensive rainfalls (rainfall 1, rainfall 2 and rainfall 3 in late May of 2009) with amounts of 21.8, 10.4, and $3.8 \mathrm{~mm}$ (total $36 \mathrm{~mm}$ ) and the intensities of 1.9, 0.38, and $0.38 \mathrm{~mm} \mathrm{~h}^{-1}$, respectively (Figure 2).

At $9.5 \mathrm{~h}$ from the beginning of the rainfall, the discharge increased and peaked three times corresponding to rainfall 1 , rainfall 2 and rainfall 3 (Figure 2). During rainfall 1, at the beginning of the discharge increase the $\mathrm{Spc}, \mathrm{pH}, \mathrm{Ca}^{2+}, \mathrm{Mg}^{2+}$, $\mathrm{Sr}^{2+}, \mathrm{HCO}_{3}^{-}, \mathrm{SO}_{4}^{2-}, \mathrm{K}^{+}$and $\mathrm{PO}_{4}^{3-}$ values reached their peaks. Then the total $\mathrm{Fe}$, total $\mathrm{Mn}, \mathrm{Al}^{3+}$ and turbidity peaked twice (Figure 2). During rainfall 2 and rainfall 3, when the discharge increased, the geochemical behaviors of all parameters became very complicated. Specifically, the turbidity, total $\mathrm{Fe}$, total $\mathrm{Mn}$, and $\mathrm{Al}^{3+}$ were relatively stable, while $\mathrm{Spc}$, $\mathrm{Ca}^{2+}, \mathrm{Mg}^{2+}, \mathrm{Sr}^{2+}, \mathrm{HCO}_{3}^{-}$and $\mathrm{SO}_{4}^{2-}$ showed dilution effects and $\mathrm{NO}_{3}^{-}, \mathrm{Cl}^{-}, \mathrm{K}^{+}, \mathrm{Na}^{+}$and $\mathrm{PO}_{4}^{3-}$ increased with increasing discharge (Figure 2). It is evident from the variation trends of the physical and chemical parameters (Figure 2) as well as the related coefficients (omitted) that there are significant correlations among most of the physical and chemical parameters and that the variation trends are consistent with each other. These findings suggest that the existence of redundant information and PCA must be used to retrieve the useful information.

\subsection{PCA and CV results}

PCA was employed for analysis of the physical and chemical parameters of the 85 water samples from JJS. The re- sults of KMO and Bartlett's test implied that PCA may support the decision to significantly reduce the dimensions of the original data set. The number of factors, called principal components (PCs) were defined according to the criterion that only $\mathrm{PCs}$ with eigenvalues exceeding 1 were selected. The PCA results are listed in Table 1. The total variance contribution rates of the three PCs were $89.2 \%$ (Table 1 ), which indicates that most information pertaining to the parameters is included. In the first principle component (PC1), Spc, pH, $\mathrm{Ca}^{2+}, \mathrm{Mg}^{2+}, \mathrm{Sr}^{2+}, \mathrm{HCO}_{3}^{-}, \mathrm{K}^{+}, \mathrm{Na}^{+}, \mathrm{SO}_{4}^{2-}$, $\mathrm{NO}_{3}^{-}, \mathrm{Cl}^{-}$and $\mathrm{PO}_{4}^{3-}$ had high component loadings of 0.909 , $0.831,0.897,0.952,0.954,0.933,0.930,0.786,0.691$, $0.836,0.959$ and 0.746 , respectively. In the second principle component ( $\mathrm{PC} 2$ ), total $\mathrm{Fe}$, total $\mathrm{Mn}, \mathrm{Al}^{3+}$, turbidity, discharge and water temperature had high component loadings of $0.953,0.847,0.861,0.856,0.66$ and 0.696 , respectively. In the third principle component (PC3), no parameters had high component loadings.

The descriptive statistics of the physical and chemical parameters of JJS are presented in Table 2. The CVs of $\mathrm{pH}$ and water temperature were only at the level of $0.00 \mathrm{n}$. The $\mathrm{CVs}$ of $\mathrm{Ca}^{2+}, \mathrm{Mg}^{2+}, \mathrm{Sr}^{2+}, \mathrm{Na}^{+}, \mathrm{HCO}_{3}^{-}, \mathrm{SO}_{4}^{2-}, \mathrm{NO}_{3}^{-}$and $\mathrm{Cl}^{-}$ were at the level of $0.0 n$. The $\mathrm{CVs}$ of $\mathrm{K}^{+}$and $\mathrm{PO}_{4}^{3-}$ were at the level of $0.1 n$. The CVs of discharge, turbidity, total Fe, total $\mathrm{Mn}$ and $\mathrm{Al}^{3+}$ were above 0.27 , which was much higher than those of the other parameters.

Among $\mathrm{PC} 1$, the parameters with higher component loadings had smaller CVs, while in PC2, the parameters with higher component loadings had larger CVs (Tables 1 and 2).

\section{Discussion}

\subsection{Sources of chemical compositions}

(i) One of the sources of chemical compositions is waterrock interactions and agricultural activities. In PC1, Spc, $\mathrm{pH}, \mathrm{Ca}^{2+}, \mathrm{Mg}^{2+}, \mathrm{Sr}^{2+}, \mathrm{HCO}_{3}^{-}$and $\mathrm{SO}_{4}^{2-}$ had high component loadings (Table 1). Ions such as $\mathrm{Ca}^{2+}, \mathrm{Mg}^{2+}, \mathrm{Sr}^{2+}$ and $\mathrm{HCO}_{3}^{-}$ are the products of karstification, and their concentrations indicate the degrees of karst water-rock interaction. Spc is the comprehensive reflection of the ions, while $\mathrm{pH}$ is mainly dependent on shifts in the equilibrium of the carbonic acid system in water [30]. At the test site, the aquifer is mainly composed of limestone and dolomite limestone. Accordingly, flowing groundwater gradually dissolves the surrounding rocks, producing high concentrations of $\mathrm{Ca}^{2+}$, $\mathrm{Mg}^{2+}, \mathrm{Sr}^{2+}$ and $\mathrm{HCO}_{3}^{-}$, which make important contributions to the hydrogeochemical formations at the test site. The higher component loading of $\mathrm{SO}_{4}^{2-}$ in $\mathrm{PC} 1$ is probably related to the dissolution of gypsum in the stratum. Therefore, it can be concluded that PC1 partially attributed to the water-rock interaction in the karst aquifer system.

The $\mathrm{K}^{+}, \mathrm{Na}^{+}, \mathrm{NO}_{3}^{-}, \mathrm{Cl}^{-}$and $\mathrm{PO}_{4}^{3-}$ also had high component loadings in PC1 (Table 1). These ions are the main 


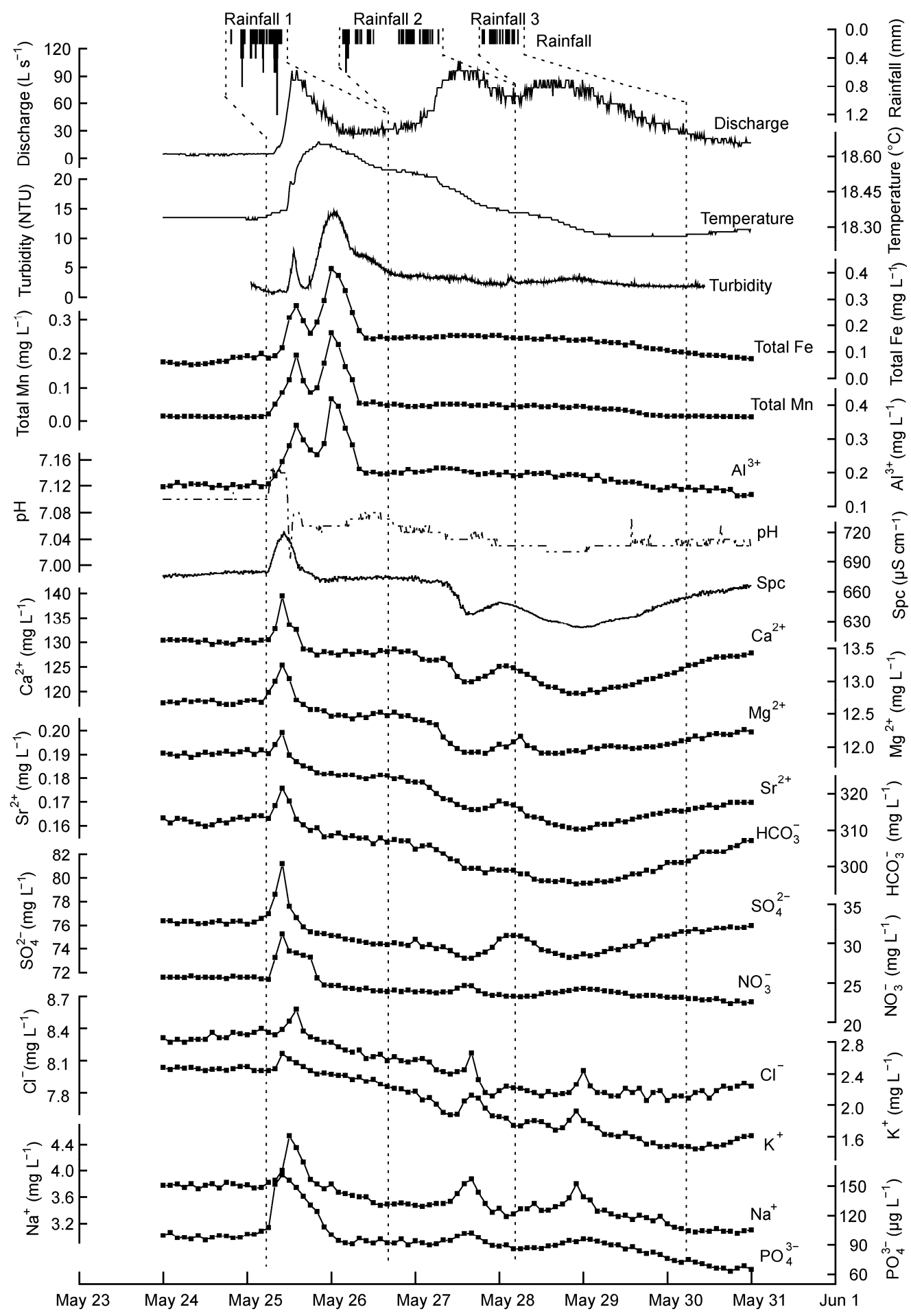

Figure 2 Response of hydrochemistry to rainfall events at the test site.

nutrients involved in eutrophication [31], and their possible sources include rain, agricultural activities, and other factors. According to previous monitoring data [25], the ions from rain can be almost negligible due to very low content of such ions in rainwater at the test site. Based on such assumptions, the main source of $\mathrm{K}^{+}, \mathrm{Na}^{+}, \mathrm{NO}_{3}^{-}, \mathrm{Cl}^{-}$and $\mathrm{PO}_{4}{ }^{3-}$ at the test site is agricultural activities. At the depression of
Ganjiacao in the upper stream of the test site, synthetic fertilizers such as urea, ammonium bicarbonate and monopotassium phosphate are used in paddy fields, with an annual fertilizing amount of $\sim 700 \mathrm{~kg} \mathrm{hm}^{-2} \mathrm{a}^{-1}$. In the watershed, manure and Nitrogen-Phosphorus-Potassium mixed fertilizer are applied in dry fields in which the main crops are corn and vegetables at an annual fertilizing rate of $\sim 800 \mathrm{~kg} \mathrm{hm}^{-2} \mathrm{a}^{-1}$. 
Table 1 Component loadings of physical and chemical data and their variance contribution

\begin{tabular}{lrrr}
\hline Parameters & $\mathrm{PC} 1$ & \multicolumn{1}{c}{$\mathrm{PC} 2$} & \multicolumn{1}{c}{$\mathrm{PC} 3$} \\
\hline Discharge & -0.409 & 0.660 & 0.525 \\
$\mathrm{Spc}$ & 0.909 & -0.177 & -0.224 \\
Temperature & 0.557 & 0.696 & -0.251 \\
$\mathrm{pH}$ & 0.831 & -0.370 & -0.039 \\
Turbidity & 0.142 & 0.856 & -0.393 \\
$\mathrm{Ca}^{2+}$ & 0.897 & -0.287 & -0.198 \\
$\mathrm{Mg}^{2+}$ & 0.952 & -0.235 & -0.089 \\
$\mathrm{Sr}^{2+}$ & 0.954 & -0.231 & -0.115 \\
$\mathrm{~K}^{+}$ & 0.930 & 0.088 & 0.088 \\
$\mathrm{Na}^{+}$ & 0.786 & 0.229 & 0.495 \\
$\mathrm{Total}^{+} \mathrm{Fe}$ & 0.158 & 0.953 & -0.086 \\
$\mathrm{Total}^{3+} \mathrm{Mn}$ & 0.403 & 0.847 & -0.048 \\
$\mathrm{Al}^{3+}$ & 0.432 & 0.861 & -0.001 \\
$\mathrm{HCO}_{3}^{-}$ & 0.933 & -0.269 & -0.163 \\
$\mathrm{SO}_{4}{ }^{2-}$ & 0.691 & -0.503 & -0.008 \\
$\mathrm{NO}_{3}^{-}$ & 0.836 & -0.016 & 0.503 \\
$\mathrm{Cl}^{-}$ & 0.959 & -0.003 & 0.063 \\
$\mathrm{PO}_{4}{ }^{3-}$ & 0.746 & 0.222 & 0.583 \\
$\mathrm{Variance}^{-}$contribution rate & $54.2 \%$ & $26.5 \%$ & $8.4 \%$ \\
\hline
\end{tabular}

Because of the intense karstification of the rock underlying these activities, nitrogen, phosphorus, potassium and similar nutrients on the surface can easily infiltrate through the soil layer and run off [32], ultimately polluting the groundwater. Furthermore, the paddy fields of Ganjiacao are left fallow in winter, during which time the local residents use them as free range areas for ducks. Therefore, the nutrients in the groundwater may also contain the metabolic products from a large number of ducks' waste. Overall, this other portion of PC1 reflects the nutrients from agricultural activities input.

(ii) Soil erosion also influences chemical compositions in the studied system. In PC2, total Fe, total $\mathrm{Mn}, \mathrm{Al}^{3+}$, turbidity, discharge and water temperature had high component loadings (Table 1). Iron, manganese and aluminum in soil are the products of soil desilicification and ferrallitization in the subtropical zone. Because of the leaching loss of calcium carbonate from the soil parent material, the main soil materials left in the soil body are Al-Fe-Mn oxide nodules and clay minerals. Turbidity is the measure of the clarity of a water source and often reflects the amount of suspended sediment present. The turbidity of the groundwater system developed in a karst conduit aquifer is usually higher during rainfall events [33-36]. In the valley of the test site, the soil layer is thick and the sinkhole is well developed. At the sides of the valley, the slope is relatively steep with a thin soil layer, which is the typical area of soil erosion. According to the comparison between samples of groundwater filtered through a $0.45-\mu \mathrm{m}$ filter membrane and samples of unfiltered groundwater, the concentrations of total $\mathrm{Fe}$, total $\mathrm{Mn}$ and $\mathrm{Al}^{3+}$ in the filtered samples were obviously lower than those in the unfiltered sample (unpublished data). These findings indicate that the substances exist as large particulates in water and that the total $\mathrm{Fe}$, total $\mathrm{Mn}$ and $\mathrm{Al}^{3+}$ in the groundwater of the test site are the products of soil desilicification and ferrallitization; i.e. the products originate from soil erosion.

During rainfall 1, two peaks of turbidity occurred, which was caused by two periods of concentrated rainfall (Figure 2). During rainfall 2 and rainfall 3, the rainfall was less

Table 2 Descriptive statistics of physical and chemical data at the test site ${ }^{\text {a) }}$

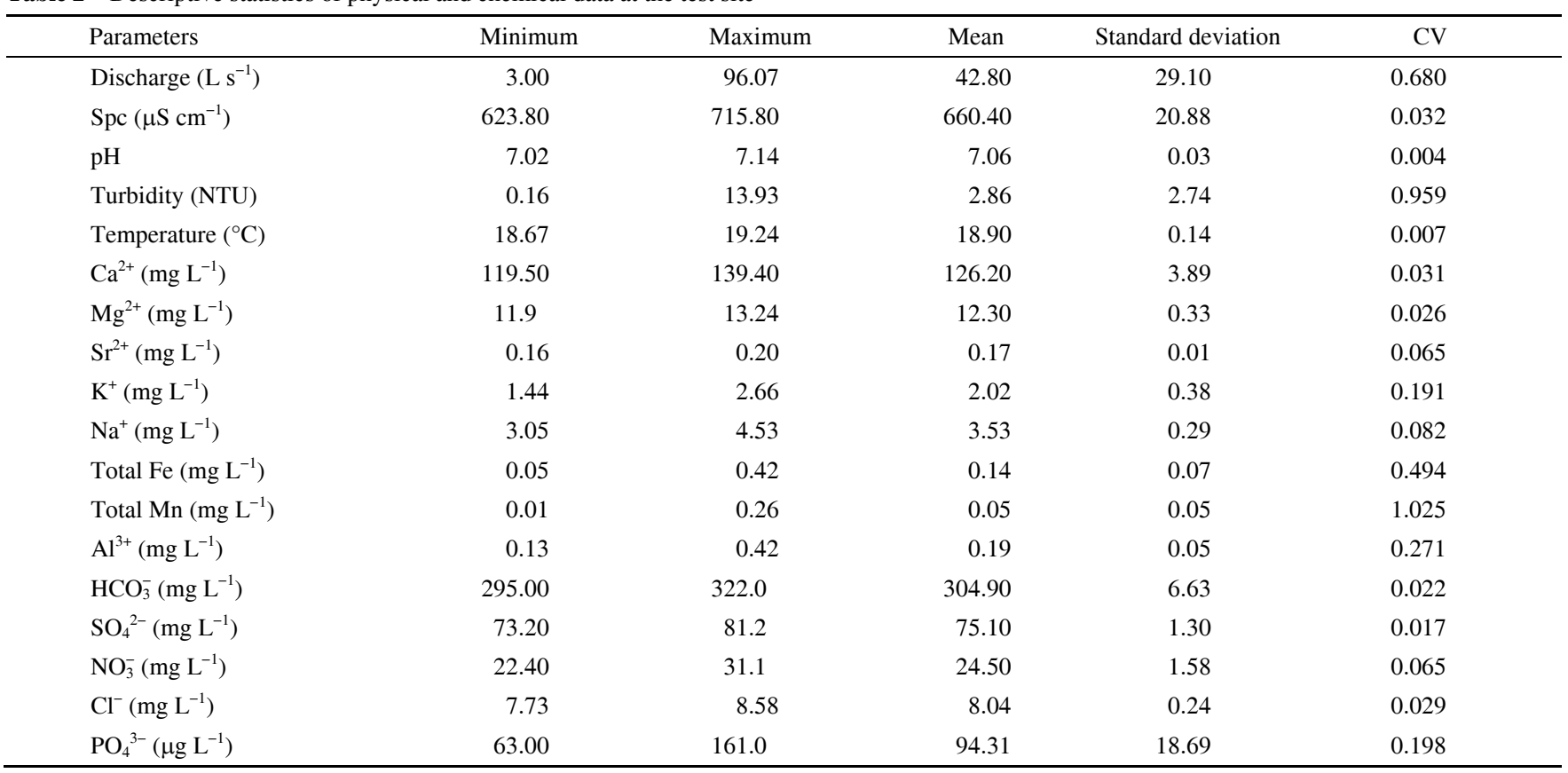

a) $\mathrm{CV}$ is dimensionless. 
concentrated and the rainfall intensity was weaker than that of rainfall 1. Although the discharge increased, the rainfall intensity was not sufficient to cause soil erosion during rainfall 1 and rainfall 2 . For this reason, the turbidity, total $\mathrm{Fe}$, total $\mathrm{Mn}$ and $\mathrm{Al}^{3+}$ were stable (Figure 2). Overall, $\mathrm{PC} 2$ reflects the soil erosion on the surface.

\subsection{Migration path of chemical compositions}

Karst aquifers can ideally be classified into two extreme forms: homogeneous and heterogeneous. The former is basically composed of fissures, pores and solution cracks characterized by low permeability and diffuse flow with a low flow velocity [37]. The physical and chemical properties of homogeneous aquifers are relatively stable [26] and they have a relatively high calcite saturation index (SIc). The latter is mainly composed of conduits characterized by high permeability and conduit flow with a high flow velocity [37]. The physical and chemical properties of heterogeneous aquifers are extremely unstable [26] and they have a relatively low SIc. Both forms of aquifer exist at the test site. According to the field high-resolution tracer test and the calculation based on the method of discharge attenuation, the mean diameter of the karst conduits is $2.27-2.72 \mathrm{~m}$, but the storage of the conduits accounts for less than $10 \%$ of the entire underground space [18]. The mean flow velocity of groundwater in the conduits is $168 \mathrm{~m} \mathrm{~h}^{-1}$ with a Reynolds number exceeding 4000, which suggests that the flow is that of a typical conduit. Aquifers such as karst fissures, pores and solution cracks develop well, with the storage accounting for more than $90 \%$ and a typical diffuse flow [18].

In $\mathrm{PC} 1$, the $\mathrm{CV}$ s of the parameters with higher component loadings (e.g. pH, Spc, $\mathrm{Ca}^{2+}, \mathrm{Mg}^{2+}, \mathrm{Sr}^{2+}, \mathrm{Na}^{+}, \mathrm{HCO}_{3}^{-}$, $\mathrm{SO}_{4}^{2-}, \mathrm{NO}_{3}^{-}, \mathrm{Cl}^{-}, \mathrm{K}^{+}, \mathrm{Na}^{+}$and $\mathrm{PO}_{4}^{3-}$, Table 1) are low (Table 2 ), which indicates that the variation amplitudes of such parameters are small in groundwater and their values are relatively stable. These findings suggest that karst aquifers have good regulatory function over these parameters. $\mathrm{Ca}^{2+}$, $\mathrm{Mg}^{2+}, \mathrm{Sr}^{2+}, \mathrm{HCO}_{3}^{-}$are the products of water-rock interactions and exist in the media of the unsaturated zone, such as karst fissures, pores and solution cracks. Some studies have shown that after being input from the surface at the test site, $\mathrm{NO}_{3}$ together with the ions produced from the water-rock interaction are kept in the diffuse flow space, unsaturated karst zone like fissures, pores and solution cracks [38]. This leads to the formation of old water, which is highly mineralized, relatively saturated and has a long retention time. The results presented above indicate that $\mathrm{NO}_{3}^{-}, \mathrm{K}^{+}, \mathrm{Na}^{+}, \mathrm{Cl}^{-}$ and $\mathrm{PO}_{4}{ }^{3-}$, which are easily dissolved in water with lower $\mathrm{CVs}$, come from agricultural activities. These findings suggest that the ions share not only the same sources, but also the same migration path. Therefore, when there is no rainfall, the chemical compositions reflected by PC1 are mainly kept in the unsaturated karst zone such as karst fissures, pores and solution cracks, and are regulated by the unsaturated zone. Once the rainfall is intense enough, the ions kept in the unsaturated karst zone are flushed out by the pressure of the water head of infiltrating rainwater, and then recharged via diffuse flow to the groundwater (Figure 3).

In PC2, the CVs of the parameters with high component loadings (e.g. turbidity, total $\mathrm{Fe}$, total $\mathrm{Mn}, \mathrm{Al}^{3+}$, discharge and turbidity, Table 1) are high (Table 2), which indicates that the variation amplitudes of such parameters caused by soil erosion are large in karst aquifers and that their values are extremely unstable. These findings suggest that the parameters are not regulated by the unsaturated zone such as karst fissures, pores and solution cracks. During rainfall events, when raindrops hit the surface soil, the splash erosion caused by the raindrops damages the structure of the soil body. The rainfall-caused surface flow then carries eroded soil particles rich in Al-Fe-Mn and other oxide

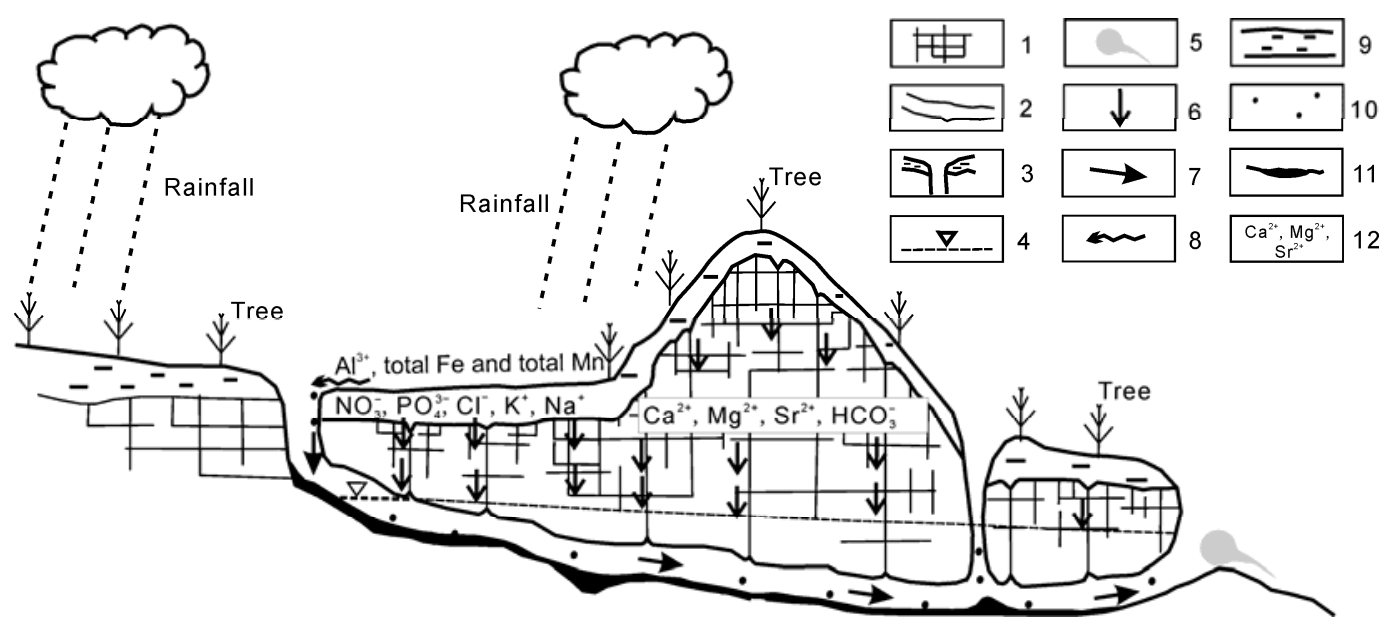

Figure 3 Conceptual model of migration of the chemical compositions in the karst aquifer system at the test site. 1, Karst fissures, pores and solution cracks; 2, karst conduit (underground river); 3, sinkhole; 4, groundwater level; 5, spring water; 6, diffuse flow; 7, conduit flow; 8, overland flow; 9, soil layer; 10, Al-Fe-Mn nodules; 11, deposit in underground river; 12, chemical compositions. 
nodules directly into the underground river (Figure 3).

After all of the chemical compositions go into the underground river they are carried by the rapid conduit flow and finally discharged at the JJS (Figure 3).

As discussed in section 3.1, the concentration peaks of the chemical compositions from water-rock interactions and agricultural activities occurred prior to that from soil erosion (Figure 2). This is probably because the rainwater infiltrated through the soil into the unsaturated zone when the rainfall began, and then washed the old water rich in ions from water-rock interactions and agricultural activities into the underground river. Accordingly, during rainfall 1, when the discharge responded to the beginning of the rainfall (period $\mathrm{E}$ ), the SIc of the groundwater increased rapidly, exceeding 0 (Figure 4). As the rainfall persisted, overland flow was generated over infiltration, which caused soil erosion. This deduction offers further evidence that the chemical compositions reflected by PC1 and PC2 occur via different migration paths.

\subsection{Eco-environmental effect}

The test site is characterized by primitive social and economic conditions. The JJS is an important water source that the local residents use as domestic water after storm events. During severe drought, the groundwater in the unsaturated karst zone contains a large number of nutrients such as N, P and $\mathrm{K}$. After a heavy rainfall, these nutrients are released and soil erosion occurs easily on the surface. As a result, the concentrations of the nutrients and total Fe, total $\mathrm{Mn}$ and $\mathrm{Al}^{3+}$ in the underground river increase sharply, deteriorating the water quality and jeopardizing the health of the local residents. Moreover, these increases threaten the overall karst groundwater ecosystem and lead to the eutrophication of water in the discharge area. Accordingly, nutrient input sources should be controlled, land-use patterns on the surface should be improved, and agricultural fields should be

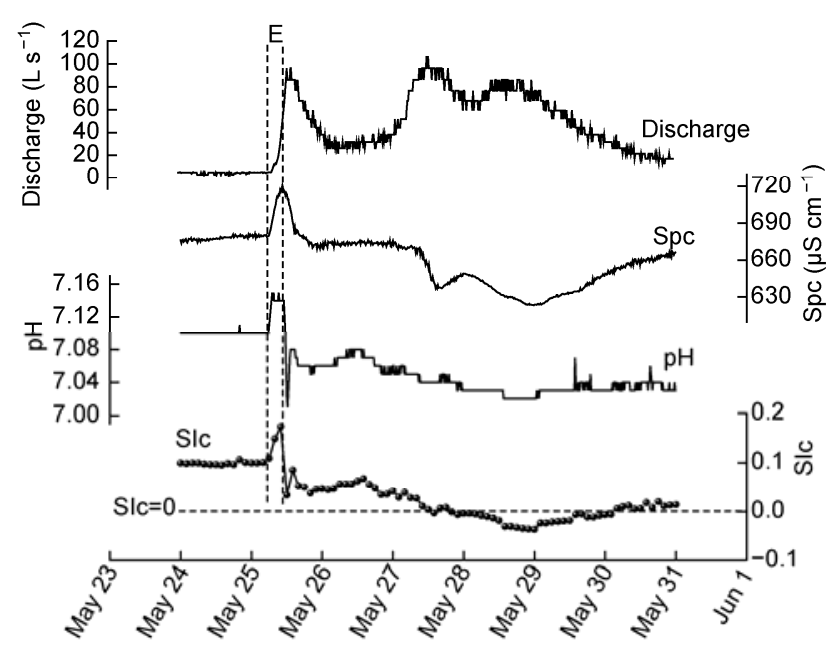

Figure 4 Dynamics of a portion of physical and chemical parameters at the test site. fertilized based on scientific plan. Only after systematic management of the karst ecosystem and effective control of nutrients from the surface that enter the karst watershed can the health of the ecosystem be ensured.

\section{Conclusions}

Rainfall events are important stages for the sufficient exchange of substances and energy between karst groundwater systems and external environments. High-resolution data monitoring is an important approach to investigate the response of the geochemical behavior of karst groundwater to rainfall events.

(1) During rainfall events at the test site, the geochemical behavior of the groundwater responded sensitively to the rainfall, and the geochemical dynamic variation was complicated, which was reflected by a large volume of redundant information. The PCA of the physical and chemical parameters of the JJS indicates that, during rainfall events, the sources of the main chemical compositions in the groundwater are water-rock interactions, agricultural activities, and soil erosion on the surface.

(2) The CVs of physical and chemical parameters indicate that there are two paths through which the chemical compositions of water that migrates into karst aquifers are altered. In the first path, water-rock interactions and agricultural sources influence the water composition. Once in the systems, this water remains until it is flushed out by the pressure of the water head of infiltrating rainwater and recharged with the diffuse flow to the underground river during rainfall events. The CVs of the concentrations of chemicals in this water are small. In the other path, the chemical compositions are influenced by soil erosion and carried directly into the underground river via surface flow. The CVs of the concentrations of chemicals in this water are large.

(3) The eco-environmental influence of the chemical compositions input from the external environment to the karst groundwater system cannot be ignored. Indeed, these chemical chemicals pose a threat to the karst ecological safety and health of the local residents. Therefore, greater efforts should be made to manage the karst ecosystem and control pollution sources.

This work was supported by the National Natural Science Foundation of China (41103068 and 41072192), the Fundamental Research Funds for the Central Universities (XDJK2012B005), the National Key Technology R\&D Program of China (2011BAC09B01 and 2006BAC01A16), the 2011 Scientific and Technical Program of the Land and Resource and Housing Management Bureau of Chongqing, the Project Supported by Karst Dynamics Laboratory, MLR and GZAR (KDL2012-08), and the Natural Science Foundation of Chongqing (CSTC2010BC7004 and CSTC2009BA0002). The authors express their gratitude to Sun Yuchuan and He Qiufang for their help with field sampling and laboratory analyses. The authors also sincerely thank Lee Anne Bledsoe and Hang Wei for their help with polishing English of the manuscript. 
1 Yuan D X. Environmental geological problems of the karst hills in SW China (in Chinese). Explor Nat, 1996, 15: 21-23

2 Yuan D X, Xue Y Q, Fu J M, et al. Countermeasures and suggestions to prevent karst underground rivers in Southwest China becoming "sewers" (in Chinese). Acad Sug Chin Acad Sci, 2007, 4: 1-14

3 Shen Z L, Zhu W H, Zhong Z S. Theoretical Basis of Hydrogeochemistry (in Chinese). Beijing: Geological Publishing House, 1993

4 Swarzenski P W, Reich C D, Spechler R M, et al. Using multiple geochemical tracers to characterize the hydrogeology of the submarine spring off Crescent Beach, Florida. Chem Geol, 2001, 179: 187-202

5 Bau M, Usui A, Pracejus B, et al. Geochemistry of low-temperature water-rock interaction: Evidence from natural waters, andesite, and iron-oxyhydroxide precipitates at Nishiki-numa iron-spring, Hokkaido, Japan. Chem Geol, 1998, 151: 293-307

6 Lang Y C, Liu C Q, Zhao Z Q, et al. Geochemistry of surface and ground water in Guiyang, China: Water/rock interaction and pollution in a karst hydrological system. Appl Geochem, 2006, 21: 887-903

7 Guo Y H, Shen Z L, Zhong Z S. Hydrochemical simulation of the groundwater chemical environmental evolution in Hebei plain, China (in Chinese). Sci China Ser D-Earth Sci, 1997, 27: 360-365

8 Wicks C M, Engeln J F. Geochemical evolution of a karst stream in Devils Icebox Cave, Missouri, USA. J Hydrol, 1997, 198: 30-41

9 Ford D C, Williams P W. Karst Geomorphology and Hydrology. Chichester: Wiley Press, 2007

10 Yuan D X, Cai G H. Karst Environments (in Chinese). Chongqing: Chongqing Press, 1998

11 Liu C Q, Lang Y C, Li S L, et al. Researches on biogeochemical processes and nutrient cycling in karstic ecological systems, southwest China: A review (in Chinese). Earth Sci Front, 2009, 6: 1-12

12 Liu Z H, Li Q, Sun H L, et al. Seasonal, diurnal and storm-scale hydrochemical variations of typical epikarst springs in subtropical karst areas of SW China: Soil $\mathrm{CO}_{2}$ and dilution effects. J Hydrol, 2007, 337: 207-223

13 Yuan D X, Liu Z H, Lin Y S, et al. Karst Dynamic Systems of China (in Chinese). Beijing: Geological Publishing House, 2002

14 Shuster E T, White W B. Seasonal fluctuations in the chemistry of lime-stone springs: A possible means for characterizing carbonate aquifers. J Hydrol, 1971, 14: 93-128

15 Langmuir D. The geochemistry of some carbonate ground waters in central Pennsylvania. Geochim Cosmochim Acta, 1971, 35: 10231045

16 Hess J, White W. Storm response of the karstic carbonate aquifer of southcentral Kentucky. J Hydrol, 1988, 99: 235-252

17 Ternan J L. Comment on the use of a calcium hardness variablity index in the study of carbonate aquifers: With reffernce to the Central Pennines, England. J Hydrol, 1972, 16: 317-321

18 Yang P H. The Hydrogeochemical Characteristics and Transportation of Suspended Particle Matters in Qingmuguan Underground River System, Chongqing, China (in Chinese). Chongqing: Southwest University Press, 2010

19 Pu J B, Yuan D X, He Q F, et al. High-resolution monitoring of nitrate variations in a typical subterranean karst stream, Chongqing, China. Environ Earth Sci, 2011, 64: 1985-1993

20 Carroll S, Goonetilleke A. Assessment of high density of onsite wastewater treatment systems on a shallow groundwater coastal aquifer using PCA. Environmetrics, 2005, 16: 257-274

21 Koonce J E, Yu Z, Farnham I M, et al. Geochemical interpretation of groundwater flow in the southern Great Basin. Geosphere, 2006, 2: 88-101

22 Lamouroux C, Hani A. Identification of groundwater flow paths in complex aquifer systems. Hydrol Process, 2006, 20: 2971-2987

23 Omo-Irabor O O, Olobaniyi S B, Oduyemli K, et al. Surface and groundwater water quality assessment using multivariate analytical methods: A case study of the Western Niger Delta, Nigeria. Phys Chem Earth, 2008, 33: 666-673

24 Rao N S, Rao J P, Subrahmanyam A. Principal component analysis in groundwater quality in a developing urban area of Andhra Pradesh. J Geol Soc India, 2007, 69: 959-969

25 Yang P H, Yuan D X, Yuan W H, et al. Formations of groundwater hydrogeochemistry in a karst system during storm events as revealed by PCA. Chin Sci Bull, 2010, 55: 1412-1422

26 Jacobsona R L, Langmuir D. Controls on the quality variations of some carbonate spring waters. J Hydrol, 1974, 23: 247-265

27 Herman E K, Toran L, White W B. Quantifying the place of karst aquifers in the groundwater to surface water continuum: A time series analysis study of storm behavior in Pennsylvania water resources. J Hydrol, 2009, 376: 307-317

28 General Administration of Quality Supervision, Inspection and Quarantine of the People's Republic of China, and Standardization Administration of the People's Republic of China. Methods for Examination of Drinking Natural Mineral Water (GB/T 8538-2008, in Chinese). Beijing: Standards Press of China, 2008

29 Zhang W L. Applicational operation of PCA in SPSS (in Chinese). Marketing Res, 2005, 12: 31-34

30 Liu Z. Necessities of measuring $\mathrm{pH}$ in situ in the study of karst hydrogeochmistry (in Chinese). Carsol Sin, 1990, 9: 310-317

31 Monteagudo L, Moreno J L, Picazo F. River eutrophication: irrigated vs. non-irrigated agriculture through different spatial scales. Water Res, 2012, 46: 2759-2771

32 Peterson E W, Davis R K, Brahana J V, et al. Movement of nitrate through regolith covered karst terrane, northwest Arkansas. J Hydrol, 2002, 256: 35-47

33 Shevenell L, McCarthy J F. Effects of precipitation events on colloids in a karst aquifer. J Hydrol, 2002, 255: 50-68

34 Pronk M, Goldscheider N, Zopfi J. Dynamics and interaction of organic carbon, turbidity and bacteria in a karst aquifer system. Hydrogeol J, 2006, 14: 473-484

35 Fournier M, Massei N, Bakalowicz M, et al. Using turbidity dynamics and geochemical variability as a tool for understanding the behavior and vulnerability of a karst aquifer. Hydrogeol J, 2007, 15: 689-704

36 Atteia O, Kozel R. Particle size distributions in waters from a karstic aquifer: from particles to colloids. J Hydrol, 1997, 201: 102-119

37 Atkinson T. Diffuse flow and conduit flow in limestone terrain in the Mendip Hills, Somerset (Great Britain). J Hydrol, 1977, 35: 93-110

38 Yang P H, Yuan D X, Ren Y R, et al. Nitrate storage and transport within a typical karst aquifer system in the paralleled ridge-valley of east Sichuan (in Chinese). Environ Sci, 2012, 33: 3124-3131

Open Access This article is distributed under the terms of the Creative Commons Attribution License which permits any use, distribution, and reproduction in any medium, provided the original author(s) and source are credited. 